Nordisk Tidsskrift for Kriminalvidenskab 2011

\title{
IKKE KUN STRENGHED - REPLIK OM DE NORDISKE RETSBEVIDSTHEDSUNDERSØGELSER
}

Af professor, Dr.Jur. Flemming Balvig, Professor Helgi Gunnlaugsson og PROFESSOR EMERITUS HENRIK THAM

\section{Summary}

In his article, Olaussen voices reservations about the methodology used in the Nordic Project. His main concern is that the project provides nonincarcerative response categories that are not actually available within the penal law for the offenses in question, and excludes incarcerative responses that are available. Olaussen worries that this may artificially reduce the tendency of respondents' to select imprisonment as the appropriate response to a given offense scenario. In addition, Olaussen criticizes the cinematic direction of the film vignettes, which he argues results in more lenient responses. The current reply notes that the main purpose of the project was not to measure public punitiveness in general, but rather the public's willingness to employ imprisonment. If the availability of alternative sanctions (like economic compensation) reduces the notion that imprisonment is necessary or appropriate, then this should not be seen as problematic. Using less imprisonment combined with other reactions has also not been widely shown in the literature. Sanctions other than imprisonment contain elements of penal value and justice, as do rehabilitation and restorative justice. The willingness to apply these very different sanctions is therefore difficult to reduce to a uni-dimensional scale. Any such scale is arbitrary, as Olaussen admits. Furthermore, films - as well as real court sessions - are always directed. It might be desirable to vary the participants and contexts in the films, but this is a matter of resources that would increase the costs of the project significantly. An exploratory study showed no evidence of sympathy for the film's "perpetrators" as implied by Olaussen. No disagreement between Olaussen and us exists as to the main conclusion of the study: We all agree that the public is hesitant to use imprisonment. Likewise, there should be no disagreement on the need to further develop the research questions and methods - something now being done in all Nordic Project countries. *

\footnotetext{
* Titel in English: Not only Severity: Reply to Leif Petter Olaussen regarding the Nordic Project on the General Sense of Justice
} 


\section{Konklusioner}

"For den norske delen av undersøkelsen er det derfor ikke grunnlag for å konkludere sterkere enn at en betydelig andel af den voksne befolkningen er nølende til bruk av fengselsstraff, og særlig til lange fengselsstraffer." Således konkluderer Leif Peter Olaussen (LPO) efter at have rejst og forsøgt at belyse nogle mulige metodekrititiske indvendinger vedrørende de nordiske retsbevidsthedsundersøgelser (dette nummer af NTfK, 2011).

Egentlig kunne det blive derved, for det er i sin essens den samme hovedkonklusion, som vi har ment kunnet uddrages af de tilsvarende undersøgelser i Danmark (Balvig, 2006; 2010), i Sverige (Jerre \& Tham, 2010) og i Island (Gunnlaugsson, 2011). For en summarisk oversigt over de nationale resultater og konklusioner, se tillige Balvig, Gunnlaugsson, Olaussen, Jerre \& Tham, 2010. Undersøgelserne er også gennemført i Finland, men herfra foreligger i skrivende stund endnu ikke resultater.

Det er dog vor vurdering, at der supplerende og uddybende er grundlag for at konkludere: I Danmark, Sverige, Island og Norge (så vidt vi kan vurdere ud fra de derfra offentliggjorte data), er der i konkrete sager, hvor retspraksis er en ubetinget fængselsstraf, en tendens til, at flertallet af den voksne befolkning, hvis de skulle dømme - uden at kende til den gældende retspraksis - i mindre omfang ville idømme ubetinget fængselsstraf eller i hvert fald en kortere ubetinget fængselsstraf end domstolene. Til gengæld ville de oftere, end det er typisk ved domstolene, anvende flere reaktioner/sanktioner/straffe i samme sag, hvilket bl.a. betyder, at f.eks. en ubetinget fængselsstraf ofte vil blive suppleret med en eller flere yderligere reaktioner/sanktioner/straffe.

\section{Undersøgelsernes formål og baggrund}

Om man opfatter dette som et udtryk for, at majoriteten af befolkningen generelt er mildere end domstolene, kan man have delte meninger om og fortolkninger af. Det er vigtigt at understrege, at retsbevidsthedsundersøgelserne som sådan ikke primært har haft til hensigt at vurdere, om befolkningen i konkrete sager generelt er mildere eller strengere end domstolene. Undersøgelsernes grundlæggende design, således som det blev udformet i Danmark i 2006, ville i så fald have været et ganske andet.

Retsbevidsthedsundersøgelserne har haft som formål at give et bud på, i hvilket omfang befolkningen i konkrete sager vil bruge den ubetingede fængselsstraf, hvis de (uden retsbelæring) skulle være dommere - og vælge/dømme i et rum af andre mulige reaktioner/sanktioner/straffe - sammenlignet med gældende retspraksis med hensyn til anvendelsen af ubetinget fængselsstraf. Det metodiske design er udformet i overensstemmelse med denne problemformulering. 
Baggrunden herfor er følgende: I 2004 nedsatte Advokatrådet i Danmark en uafhængig og bredt sammensat arbejdsgruppe (med repræsentanter fra bl.a. politi/ anklagemyndighed, advokatstand, kriminalforsorg og forskning), der skulle overveje fremtidens straffe (Balvig et al, 2006). Baggrunden var en stigning i Danmark i antallet og længden af korte, ubetingede fængselsstraffe. Blandt sine forskellige aktiviteter gennemførte arbejdsgruppen en undersøgelse af, hvorvidt befolkningen ville anvende relativt korte fængselsstraffe i konkrete sager i samme omfang og på samme måde som domstolene (Balvig, 2006).

Efter undersøgelsens publicering kom der fra politisk hold, bl.a. fra den daværende justitsminister, kritik af, at man ikke havde undersøgt, hvordan befolkningen ville dømme i "alvorlige sager", hvormed mentes sager, hvor retspraksis var en længere ubetinget fængselsstraf, som eksempelvis i sager vedrørende narkotikasmugling, voldtægt og røveri. I forlængelse heraf besluttedes det at gennemføre en ny undersøgelse i 2009, metodisk set som en tro kopi af 2006-undersøgelsen, men med sager hvor retspraksis var ubetingede frihedsstraffe fra 1 år og opefter (Balvig, 2010). Undersøgelsen finansieredes af det danske justitsministerium. De ligeledes i 2009 gennemførte undersøgelser i Finland, Sverige, Island og Norge er af komparative hensyn gennemført på samme måde som den danske, bortset fra kortere fokusgruppeforløb, og en fra land til land noget forskellig udformning af den sidste del af fokusgruppemøderne. Parallelundersøgelserne i Finland, Sverige, Island og Norge er finansieret af Nordisk Samarbejdsråd for Kriminologi suppleret med diverse nationale bevillinger.

\section{Folkets dom - en flerdimensional størrelse}

De i alle undersøgelser anvendte spørgeskemaer indledes på forsiden med spørgsmålet: Hvordan vil du dømme? Også i ledsagebreve m.v. præciseres, at opgaven består i at være dommer i en række konkrete sager. For at sikre en ensartet fortolkning af, hvordan svarene - "dommene" - skal fortolkes, er en serie af mulige reaktioner/sanktioner/straffe beskrevet kort. Intetsteds er der omtalt, hvad man kan eller skal lægge vægt på, når man dømmer.

Imidlertid er det naturligvis interessant, hvad det er for kriterier eller hensyn, svarpersonerne har dømt ud fra. Fokusgruppediskussionerne i flere af landene samt efterfølgende små metodestudier i såvel Sverige som Danmark viser, at folk ofte tager flere hensyn, og at der så at sige er flere "forklaringer" på deres dom. Det centrale i sammenhængen her er, at svarpersonerne i forskellig grad og i forskelligt omfang i deres domme har inddraget andet end deres opfattelse af forbrydelsens alvorlighed og deres opfattelses af de enkelte reaktioners/sanktioners/straffes strenghed i deres domme, f.eks. mindskelse af de skader m.v., der har været påført offeret og/eller rehabilitering. 
Hvor ofte dette er sket, hvordan det er sket, og for hvem det er sket, har undersøgelserne ikke haft som formål at afdække - og kan ikke ud fra de foreliggende data blot tilnærmelsesvist afdækkes. At inddrage alle de enkeltdomme, svarpersonerne har afgivet, og ud fra dette ad hoc konstruere en påstået generel endimensional skala, der måler, hvor "strenge" svarpersonerne er i forhold til hinanden - intentionelt sammenlignelig med en tilsvarende for domstolene - er at gøre vold på det indsamlede datamateriale. Det er simpelthen ikke muligt. Man kan ikke skabe endimensionalitet ud af flerdimensionalitet, når der ikke foreligger de nødvendige data og oplysninger til at skille dimensionerne ad, uanset hvilke krumspring, man benytter sig af.

\section{Folkets dom - en sammensat størrelse}

I LPO's strenghedsoptik er det et særligt problem, at svarpersonerne i deres domme har kunnet vælge op til to forskellige af de opstillede mulige reaktioner/sanktioner/ straffe. LPO mener, at dette kan få nogle til at undlade at vælge ubetinget fængsel. Naturligvis, må man sige, bl.a. fordi dette øger muligheden for, at svarpersonerne kan inddrage flere hensyn og dimensioner i deres domme. Selv om man forestillede sig, at alle reaktioner m.v. var blevet pådømt ud fra en alvorligheds-strengheds overvejelse, ville man stå tilbage med problemer, som i væsentlig grad ville være skønsmæssige - hvilket LPO da også erkender - og en skala, der i udgangspunktet byggede på en mere end tvivlsom formodning om intervalegenskaber (selv om den senere fortolkes som en rangordningsskala, ja faktisk nedgraderes til en klassifikationsskala med angivelse af modus). Endvidere vil de enkelte skalaværdier være uden entydig mening, dvs. man kan ikke af dem aflede, hvordan folk har dømt (flere kombinationer af reaktioner mv. kan føre til samme skalaværdi).

I vor optik er det ikke noget problem overhovedet, at svarpersonerne i deres domme har kunnet vælge op til to reaktioner m.v. Tværtimod. At svarpersonerne faktisk ofte vælger to reaktioner m.v. viser jo, at det ville have været kunstigt kun at have haft én svarmulighed. Faktisk er det - i vor optik og med hensyn til den problematik, vi har villet afdække - et problem, at svarpersonerne kun kunne vælge op til to reaktioner m.v. Svarpersonerne burde have kunnet vælge alle de reaktioner m.v. af de opstillede, de mente, skulle indgå i en dom, og ideelt endvidere have haft mulighed for at tilføje reaktioner/sanktioner/straffe, der ikke var anført såsom konfiskation, udvisning m.v.

Heller ikke domstolene er jo i deres domme som udgangspunkt begrænset til kun at skulle vælge én reaktion/sanktion/straf. I praksis er forskellige former for "kombinationsdomme" almindeligt forekommende. I forhold til de dommerpaneler, der har været anvendt i retsbevidsthedsundersøgelserne, har vi - når vi kigger tilbage - været for fokuseret på blot at få retspraksis kortlagt med hensyn til 
hovedsanktionen (dvs. spørgsmålet om fængselsstraf eller ikke fængselsstraf, og i førstnævnte tilfælde hvor lange fængselsstraffe). Vi burde også have spurgt efter eventuelle bud på "kombinationsdomme".

En randomiseret gennemført test i Danmark af et spørgeskema med op til to valgmuligheder og et spørgeskema med ubegrænsede valgmuligheder tyder på, at det ikke ville have gjort den helt store forskel. Tendensen går i retning af, at når svarmulighederne er ubegrænsede, så er der endnu færre, der har ubetinget fængselsstraf blandt deres valg af reaktioner/sanktioner/straffe, og når det er tilfældet, er de endnu kortere end ved spørgeskemaet med op til to valgmuligheder. Det er altså en forlængelse af samme tendens, som LPO er inde på, når man sammenligner svarene på et spørgeskema med op til to valgmuligheder med svarene på et spørgeskema, hvor de udspurgte "dommere" stilles over for den kunstige og virkelighedsfjerne situation med kun én valgmulighed.

Når vi i den oprindelige undersøgelse i Danmark i 2006 valgte at begrænse svarmulighederne til maksimalt to, var det udelukkende af analytiske grunde. Det er svært nok analytisk at håndtere max. to svarmuligheder ud af et meget stort antal alternativer, men virkelig kompliceret at håndtere ubegrænsede muligheder (inklusiv åbne svar).

En efterfølgende henvendelse til et dommerpanel, ligeledes i Danmark, tyder på, at der i retspraksis ved nogle af de anvendte domme i en del tilfælde i praksis ville blive idømt en eller flere af de supplerende reaktioner/sanktioner/straffe, men at dette som absolut hovedregel ikke ville ændre den hovedsanktion (fængselsstraffen og dens længde), dommerpanelerne har peget på.

\section{Folkets dom - andet end traditionel straf}

LPO rejser også spørgsmålet om de - som han kalder det - "ekstralegale" reaktioner/sanktioner/straffe, som svarpersonerne har kunnet vælge, først og fremmest "behandling" og "økonomisk kompensation til offeret". Det er en vanskelig problematik. Vi deler LPO's vurdering af, at hvis de ikke havde været med, så var der flere, der ville have valgt ubetinget fængselsstraf og måske, måske-ikke - her er vi mere i tvivl - længere ubetingede fængselsstraffe.

I en snæver sammenligning på det eksisterende straffesystems præmisser ville vi sikkert uden de "ekstralegale" svarmuligheder have fundet mindre og færre forskelle mellem retspraksis og befolkningens domme. Hvor meget mindre og færre er svært at vurdere, men baseret på beregninger på de eksisterende data, ville der dog langtfra være tale om nogen "udligning". Et metodestudie gennemført i Sverige, hvor man lod svarpersonerne dømme henholdsvis med og uden forkundskab om, at offeret havde fået en økonomisk kompensation, viste, at fraværet af en sådan "ekstralegal" reaktion ikke øgede længden af den idømte fængselsstraf. 
Der findes ikke noget rigtigt svar på, om man skal medtage "ekstralegale" reaktioner mv. i en undersøgelse, hvor man sammenstiller befolkningen som dommere, og det der faktisk foregår eller kan foregå ved domstolene. Den viden, vi får frem, og de konklusioner, der kan drages, afhænger af det ringhjørne, man placerer sig i.

Vurderet ud fra perspektivet befolkningen som dommere viser medtagningen af de "ekstralegale" svarkategorier det interessante, at en betydelig del af befolkningen åbenbart synes, at man helt eller delvist skal kunne idømmes noget andet end den traditionelle og eksisterende (fængsels)straf. En del af befolkningen synes oven i købet at foretrække "ekstralegale" reaktioner frem for ubetinget fængselsstraf. Set i dette perspektiv er problemet ikke, at vi har "ekstralegale" svarekategorier med, men - jf. også diskussionen om det antal reaktioner/sanktioner/straffe der kan vælges - at vi har for få af disse med, og at vi ikke har åbnet for reaktioner/ sanktioner/straffe som de udspurgte selv kan formulere (åbne spørgsmål). Vi er gennem at begrænse de "ekstralegale" svarkategorier ikke blevet så kloge på "folkets domstol", som vi kunne være blevet. Det er vor hypotese, at hvis vi havde taget endnu flere "ekstralegale" svarmuligheder med (herunder "åbne"), så ville der have været endnu færre, der ville have valgt (længere) ubetingede frihedsstraffe.

Specielt vedrørende "behandling" ville det have været formålstjenligt, om man i undersøgelserne nærmere havde specificeret, hvad der mentes hermed, f.eks. om det er frivillig eller tvangsmæssig behandling, ambulant eller ikke-ambulant osv. Man kan godt forestille sig, at der her i så henseende har været visse nationale forskelle på spil. For Danmarks/Islands/Sveriges vedkommende viser fokusgruppediskussionerne, at de, der har valgt "behandling", i helt overvejende grad har forestillet sig det som et vilkår i forbindelse med en betinget dom. Havde vi i undersøgelserne sondret mellem forskellige betingede domme med og uden specificerede vilkår, ville der næppe have været mange tilbage, der havde valgt en enkeltstående kategori som "behandling", og - selv om vi i den forbindelse havde fjernet en af de "ekstralegale" svarmuligheder - sandsynligvis heller ikke måleligt flere, der ville have valgt ubetinget fængselsstraf. På grund af de fejlopfattelser, der synes at eksistere hos en del vedrørende den betingede dom, og hvad denne består i og kan bestå af, burde den nok have været medtaget på en mere udfoldet måde blandt svarmulighederne og/eller givet en fyldigere beskrivelse i introduktionen til spørgeskemaerne.

LPO har som nævnt også "økonomisk kompensation til offeret" med i det, han beskriver som "ekstralegale" svarmuligheder, men selv dommerne har - i hvert fald i nogle af de nordiske lande - mulighed for at give dette i tillæg til straffen. Skulle der være nogen konsekvent logik i LPO's forsøg på strengheds-skaleringer og sammenligninger af disse, burde han vel også tillægge de relevante "ekstrale- 
gale" reaktioner mv., som f.eks. økonomisk kompensation, ikke blot til befolkningens domme, men også til domstolenes. Det synes LPO ikke at have gjort.

LPO inddrager slet ikke det forhold, at dommerne i det hele taget har et arsenal af det LPO nok ville kalde "ekstralegale" reaktioner, som vi ikke har givet befolkningen mulighed for at vælge, såsom konfiskation, udvisning mv. Hvordan mon det ville have påvirket befolkningens domme, hvis man havde haft disse med som valgmuligheder?

\section{Folkets dom - mere vægt på genoprettelse?}

Skulle man forsigtigt ud fra befolkningens valg af reaktioner i det hele taget (herunder dens valg af "ekstralegale" sanktioner samt - i særdeleshed - den måde der er blevet argumenteret for de enkelte valg på under fokusgruppediskussionerne - i det mindste i Danmark/Island/Sverige) forsøge at pejle sig ind på de væsentligste forskelle mellem "folkets domme" og "juristerne domme", udover hvad der er anført indledningsvist af hovedkonklusioner, så synes det at være, at befolkningen tendentielt lægger større vægt på, hvad de forestiller sig kan bidrage til at resocialisere den tiltalte samt bringe offeret lettere over det skete. Denne tendens ville nogen nok vælge at kalde for en tendens i retning af restorative justice eller genoprettende retfærdighed: En fokusering på at genoprette de skete skader for offeret og at udbedre de skader, man ser hos tiltalte - med den tiltalte som en aktiv part i dette spil. Den kriminalpolitiske udfordring fra "folkets domstol" er måske derfor - snarere end kun at ændre på de eksisterende straffe - at ændre på selve domstolssystemet og de principper, det styres af i sine reaktionsvalg og som jo først og fremmest er alvorlighed-strenghed-proportionalitet.

\section{Folkets dom - så virkelighedsnar som muligt}

Selv med et ubegrænset antal svarmuligheder er dette at skulle pådømme en sag ud fra læsning af et kortfattet referat af sagen på et stykke papir kunstig og noget virkelighedsfjernt for den type alvorlige sager, som der her er tale om. Dette nævnes også af LPO. Det er derfor, at der i retsbevidsthedsundersøgelserne tillige er benyttet fokusgruppemøder, hvor repræsentative udsnit af befolkningen, først individuelt og senere i fællesskab, har skullet pådømme konkrete sager vist på film. LPO implicerer, at dette er valgt for at kunne afprøve den såkaldte nærhedshypotese. Det er imidlertid på ingen måde den oprindelige begrundelse. Den oprindelige begrundelse var at gøre domssituationen for befolkningen mindre kunstig og mindre virkelighedsfjern, dvs. skabe en domssituation som ligger tættere på den situation et dommerkollegium befinder sig i en faktisk retssag: 1) Man ser og hører, hvad forsvarer, anklager, tiltalte og vidner har at sige, 2) Man får herved nøjagtig de samme oplysninger om sagen som i en rigtig retssag, 3) Man får yderligere viden 
om de enkelte reaktioners/sanktioners/straffes karakter og udformning (det gælder dog vist nok ikke i den måde fokusgruppemøderne er afviklet på i Norge?), og 4) Man får lejlighed til at diskutere sagen og reaktionerne/sanktionerne/straffene med andre "meddommere". Fordi dette set-up er det mest virkelighedsnære, er det vor opfattelse, at det også er de domme, der komme ud af dette (den sidste dom i fokusgruppemøderne), som det er mest relevant at sammenligne med faktisk retspraksis.

LPO har selvfølgelig ret $\mathrm{i}$, at det kan spille en rolle, hvordan de agerende i de spillede og filmede retssager virker på dem, der ser dem. Det gælder ikke mindst vedrørende oplevelsen af tiltaltes person. Det ved vi er tilfældet fra utallige socialpsykologiske forsøg, og ikke mindst fra vidnepsykologien, og det er afgjort en svaghed ved de gennemførte undersøgelser indtil nu, at hovedkonklusionernes generalitet ikke er afprøvet i forhold til denne problematik.

Tanken er da også, at dette skal forsøges afprøvet som et led i og som en fortsættelse af de pågående undersøgelser. Vi har ikke tiltro til LPO's idé om, at en faglig vurdering af hvilket eller hvilke budskaber, der synes at være indlejret i de eksisterende film, foretaget af en fokusgruppe bestående af personer med en faglig baggrund i filmregi, skulle kunne afklare problematikken. Mere målret og relevant ville det være at få fokusgrupper sammensat af repræsentative befolkningsudsnit til at diskutere, hvilke budskaber de opfatter. Her er vi allerede et stykke på vej via de kommentarer m.v., der er fremkommet under de afholdte fokusgruppemøder. For de danske fokusgruppers vedkommende var det således bl.a. tydeligt, at der gennemgående ikke var megen sympati for tiltalte som person. Han oplevedes gennemgående som en usympatisk og utroværdig person, og i stigende grad, jo mere alvorlig handling der var tale om, hvilket - som man kunne forvente - tyder på et samspil i oplevelsen mellem handling og person.

For mere definitivt at afklare "budskabets" karakter og dets mulige indflydelse på, hvordan der dømmes, vil det eneste rigtige dog være eksperimentelt at variere dels personerne (f.eks. med hensyn til køn, alder osv.) og dels instrueringen. Det er netop dette, der forsøges i de fortsatte undersøgelser. Foreløbig er der i forløbende danske metodestudier forsøgt evalueret, hvilke forskelle det eventuelt medfører, om man ser filmene, om man kun hører lyden, eller om man kun lceser manuskriptet. Tillige er det læste manuskript forsøgt varieret på forskellige måder i forhold til forskellige grupper. Eksperimenter med at variere selve filmene er desværre en bekostelig affære.

De første nævnte eksperimenter tyder på, at det $g ø r$ en forskel, hvordan man møder sagen, men langt fra i en størrelsesorden, der påvirker de indledningsvist nævnte hovedkonklusioner. De i de nuværende film medvirkende dommere, advokater mv. har endvidere generelt givet udtryk for, at sceneriet og de medvirkende 
er ganske "typiske" og "genkendelige" i forhold til det, de normalt oplever i dagligdagen. Forestillingen om, at filmene skulle kunne være eller instrueres på en måde, så de er "neutrale", "objektive" eller egentlig repræsentative, anser vi for at være en urealisabel og en helt urealistisk utopi.

\section{Folkets dom - når den kommer tæet på}

Selv om idéen med retsbevidsthedsundersøgelserne ikke har været at teste nærhedshypotesen, kan man selvfølgelig godt diskutere, om ikke de forskelle, der eksempelvis findes mellem at dømme ud fra sager beskrevet kortfattet på papir, og sager man ser på film, kan forklares på denne måde. Det forudsætter helt grundlæggende, at man definerer "nærhed", hvilket LPO ikke gør noget forsøg på (heller ikke i et uddybende paper specifikt om denne problematik, jf. Olaussen, 2011). For os er en vigtig dimension i nærhed den grad og ikke mindst den kompleksitet af viden eller information, man har om et andet menneske og dets handlinger, og netop på denne måde er nærheden størst ved filmene og kan være en væsentlig faktor bag, at man her er mindre tilbøjelige til at idømme lovens strengeste straf, ubetinget fængselsstraf (jf. også Snare, 2011), end når man dømmer på baggrund af et kort skriftligt referat.

Selv i de arrangerede fokusgruppemøder og i mødet med filmene må man erkende, at nærheden - i ovennævnte betydning - ikke er så stor som i en faktisk retssag. Der forbliver en vis kunstighed og virkelighedsfjernhed over set-up'et. Hvor meget dette betyder, ved vi ikke og får måske aldrig at vide.

\section{Folkets dom - fra flere sider}

I en del af de danske undersøgelser er deltagerne i fokusgruppemøderne afslutningsvis blevet spurgt, om de troede, de ville have dømt anderledes, hvis det havde været virkelighed. Omkring halvdelen følte sig overbeviste om, at det ikke ville gøre nogen forskel; godt en femtedel mente, at det var umuligt at sige, mens de resterende mente, at de så ikke ville være helt så strenge. Ikke en eneste svarede, at de - hvis det havde været virkelighed - så nok ville være mere tilbøjelige til at anvende (længere) ubetingede fængselsstraffe - eller i det hele taget ville være "strengere" i forhold til deres egen oplevelse af, hvad dette vil sige.

Af en eller anden grund fokuserer LPO i sin artikel udelukkende på mulige metodekritiske problemer, som efter hans mening kan svcekke hovedkonklusionen. At der i undersøgelserne er tale om en uforpligtende "leg" og ikke virkelighed, er et blandt flere eksempler på metodiske problemer, som måske snarere, jf. ovenstående, bestyrker hovedkonklusionen. Objektivitet forudsætter - på mange måder endda - triangulering. Objektivitet kan ikke tilnærmes med kun ét udsigtspunkt.

Med henblik på at skabe en domssituation tættest muligt på virkeligheden er 
det et beslægtet spørgsmål, om der ikke er gjort for lidt ud af (ligeså grundigt som om handlingerne og personerne) at informere "dommerne" om karakteren af de enkelte reaktioner/sanktioner/straffe: Meget tyder f.eks. på, at der er mange fejlopfattelser af, hvad en ubetinget fængselsstraf vil sige. Under fokusgruppemøderne (i hvert fald i Danmark) - hvor det ikke var muligt at korrigere, fordi der ikke var fagfolk til stede - fremstod det eksempelvis som udbredte forestillinger, at alle indsatte har ret til prøveløsladelse (efter halv tid) og orlov/udgang hver weekend. Det fremstod også som en udbredt forestilling, at åbne fængsler er steder, hvor man om dagen kan gå og komme som man vil. Vi finder det sandsynligt, at når så relativt stor en del af befolkningen i alle landene ifølge de gennemførte undersøgelser har den opfattelse, at det at sidde i fængsel nærmest er som at være på hotel, så hænger det i væsentlig grad sammen med disse misopfattelser, og at færre ville opfatte det som hotelophold, hvis de vidste, hvordan det faktisk var. Det er vel så også tænkeligt, at man herefter ville være endnu mere utilbøjelige til at idømme ubetinget fængselsstraf eller i givet fald af kortere længde. Uanset rigtigheden heraf bør man i fremtidige undersøgelser i bestræbelserne på at skabe så virkelighedsnære domssituationer som muligt gøre mere ud af viden om indholdet af de mulige domme, mennesker bliver bedt om at afsige.

Balvig, Flemming (2006): Danskernes syn på straf. Advokatsamfundet. København.

Balvig, Flemming (2010): Danskernes retsfølelse og retsfornuft - et forspil. Det Juridiske fakultet, Københavns Universitet, København.

Balvig, Flemming et al (2006): Ni anbefalinger fra gruppen om fremtidens straffe. Advokatsamfundet. København.

Balvig, Flemming, Helgi Gunnlaugsson, Kristian Jerre, Leif Petter Olaussen og Henrik Tham (2010):"Den nordiske retsbevidsthedsundersøgelse". Nordisk Tidsskrift for Kriminalvidenskab, 97. årgang, nr. 3, s. 232-250.

Gunnlaugsson, Helgi (2011): Vil offentligheden i Island have strengere straffe end domstolene?. Manuskript. Oplæg ved forskerkonference arrangeret af Nordisk Samarbejdsråd for Kriminologi, maj 2011, i Stockholm (forventes at blive publiceret i konferencerapport).

Jerre, Kristina og Henrik Tham (2010): Svenskarnas syn på straff. Rapport 2010:1. Stockholms Universitet, Kriminologiska Institutionen. Stockholm.

Snare, Annika (2011): Kommentar til Leif Peter Olaussen: "Fører noerhet til tiltalte til mildere straff?" Manuskript. Oplæg ved forskerkonference arrangeret af Nordisk Samarbejdsråd for Kriminologi, maj 2011, i Stockholm (forventes at blive publiceret $\mathrm{i}$ konferencerapport). 
Olaussen, Leif Petter (2010): Straffenivået og folks holdninger til straff $i$ Norge. Rapport. Institutt for kriminologi og rettssosiologi, Universitetet i Oslo. Oslo. Olaussen, Leif Petter (2011): Fører noerhet til tiltalte til mildere straff? Manuskript. Oplæg ved forskerkonference arrangeret af Nordisk Samarbejdsråd for Kriminologi, maj 2011, i Stockholm (forventes at blive publiceret i konferencerapport). 